\title{
Genetic Diversity and Population Structure of Brassica juncea by Random Amplified Polymorphic DNA (RAPD)
}

\author{
Yunghee Oh', Sung Gi Moon², Yang Hee Chae'2, Hwa Jin Hong², Min Cheol Cho, So Hye Park \\ and Man Kyu Huh*
}

\author{
Department of Molecular Biology, Dongeui University, Busan 614-714, Korea \\ ${ }^{1}$ Department of Chemistry, Dongeui University, Busan 614714, Korea \\ ${ }^{2}$ Department of Biology, Kyungsung University, Busan 608-736, Korea
}

Received August 11, 2010 /Accepted September 11, 2010

\begin{abstract}
This study was conducted to examine the genetic diversity and population structure of 17 Brassica juncea populations in Korea. The technique of random amplified polymorphic DNA (RAPD) produced 60 polymorphic loci and 18 monomorphic loci. In a simple measure of intraspecies variability by the percentage of polymorphic bands, the Jindo population of Cheonnam showed the highest $(29.5 \%)$. The cultivar exhibited the lowest variation (12.8\%). Mean number of alleles per locus $(A)$ and the effective number of alleles per locus $\left(A_{\mathrm{E}}\right)$ were 1.221 and 1.167 , respectively. As the typical populations of this species were small, isolated, and patchily distributed in their natural populations, they maintained a low level of genetic diversity of fourteen primers. On a per locus basis, total genetic diversity values $\left(H_{\mathrm{T}}\right)$ and interlocus variation in the within-population genetic diversity $\left(H_{S}\right)$ were 0.347 and 0.141 , respectively. On a per-locus basis, the proportion of total genetic variation due to differences among populations $\left(G_{\mathrm{ST}}\right)$ was 0.589 . This indicated that about $58.9 \%$ of the total variation was among populations. The estimate of gene flow, based on $G_{\mathrm{ST}}$, was very low among Korean populations of $B$. juncea $\left(N_{m}=0.617\right)$. These results suggest that the geological distance dispersal of wild $B$. juncea is the best event. RAPD markers are very effective in classifying natural population levels of $B$. juncea in Korea.
\end{abstract}

Key words : Random amplified polymorphic DNA (RAPD), genetic diversity, Brassica juncea

\section{서 론}

우리나라의 겨자(Brassica juncea Czern et Cosson)는 중국에 서 유입된 채소류로 서양에서는 mustard greens, Nepali Rayo, Chinese mustard, 혹은 leaf mustard로 알려져 있다. 해안지역, 특히 남부지역(특히 진도, 완도 지역 주변)을 중심으 로 주로 갓(Brassica juncea Czern et Cosson var. integrifolia Sinskaja)이 재배되고 있다. 여수 지역에서는 '돌산갓'이라 하 여 역시 겨자의 한 변종인 갓 품종이 일본에서 도입되어 재배 되고 있다.

겨자의 잎은 타원형 또는 도란형이며 끝은 둥글고 엽저 부 분은 좁아져 있고 거치가 있다. 줄기에 부착된 겨자의 잎은 장타원형 피침형이다. 겨자는 봄부터 여름까지 개화하며 꽃은 노랑이고 십자형이며 총상화서이다. 겨자의 잎은 식용으로 이 용되며 열매는 각과이며 꼬투리는 원기둥 모양이고, 종자는 겨자를 만드는데 이용된다. 핵형은 $\mathrm{n}=18$ 이다[13].

식물 시료로부터 종간 종내 다형성(polymorphism)을 평가 하기 위해 다양한 분자 마커(marker)가 이용되고 있다. 이들 마커들은 크게 두 가지로 나눌 수 있다. 첫째 DNA와 RNA의

*Corresponding author

Tel : +82-51-890-1529, Fax : +82-51-890-1521

E-mail : mkhuh@deu.ac.kr
혼성에 근거한 마커(hybridization based markers)이다. 즉, 제 한효소로 절단한 DNA를 표식된 탐침자로 혼성시키는 방법이 다. 또 하나는 중합 효소 연쇄 반응(polymerase chain reaction, $\mathrm{PCR}$ )에 의한 마커로 특정 시발체(primer)를 $\mathrm{PCR}$ 기기로 증폭 시켜 전기영동으로 밴드 양상을 보는 방법이다. 이 방법은 온 도와 중합효소에 민감하여 재현성이 요구된다.

RAPD (Random amplified polymorphic DNA)는 시발체 로 상응하는 게놈 $\mathrm{DNA}$ 상 임의 유전자를 증폭하는 것으로 근 연종간 구별에 널리 쓰이고 있다[2,21]. RAPD분석은 다른 생 물학적 분자 마커에 비해 신속하고, 서열에 대한 예비적인 지 식이 그다지 필요하지 않아 실험의 경비도 다른 기법에 비해 저렴하여 종 분류와 분화에 대한 연구로 PCR 개발에 힘입어 널리 사용되고 있다.

또한 RAPD기법은 간편한 종 간, 종 내, 집단 간 다형 검출 법으로 널리 사용되고 있다. 사용하는 주형 DNA의 양도 몇 나노그람정도로도 증폭이 가능함으로 DNA 추출도 대폭적으 로 줄일 수 있다. RFLP (Restriction Fragment Length Polymorphism) 마크에 비하면 재현성이 좋지 않는 경우가 있 어 주의가 필요하다. 또 $\mathrm{DNA}$ 를 주형으로 사용하여 표현형질 마크나 임의의 마크에 연계한 RAPD 마크를 간단하게 얻으므 로 유전자의 다양도를 진행하는 경우에 유력한 방법 중의 하 나이다[11,16]. 
본 연구의 목적은 한국 내 자생하는 겨자 집단의 유전적 다양성과 집단의 분화를 RAPD로 가능한지 검증하고자 하였 으며 재배 계통과 비교하였다.

\section{재료 및 방법}

\section{재료와 DNA 추출}

집단 간 분석을 위하여 한국에 자생하는 겨자 17 집단을 집단 간 임의 교배가 일어나지 않을 만큼 충분한 거리를 두 고 채집하였다(Table 1). 또 집단 내 차이를 비교하기 위하여 한 집단 당 20 개체로부터 각각 하나의 잎에서 $\mathrm{DNA}$ 를 추출 하였다.

각 식물체로부터 DNA를 추출하기 위하여 Plant DNA Zol Reagent (Life Technologies Inc., Grand Island, New York, USA)를 사용하였는데 사용자의 지침서에 의거하여 추출하였 다. 추출한 DNA를 건조시킨 후 TE $100 \mathrm{ul}$ 에 용해하였다. 3일 간 냉장보관한 후 $\mathrm{DNA}$ 정량을 체크하여 $\mathrm{DNA}$ 농도가 균질하 게 조정하였다.

\section{$\mathrm{RAPD}$ 분석}

수집한 개체들의 DNA분석을 위한 예비실험에서 유전자 증 폭이 일어나는지 오페론사(Operon Technologies, Alameda)의 시발체로 조사하였다(Table 2). RAPD band를 보이는 decamer primers를 선발하여 사용하였다.

$\mathrm{DNA}$ 증폭 반응들은 $25 \mu \mathrm{l}$ 의 반응액을 함유하는 $0.6 \mathrm{ml}$ 튜브 에 주입하였다. 즉 $10 \mathrm{mM}$ Tris-Hcl, $\mathrm{pH} 8.8,50 \mathrm{mM} \mathrm{MgCl}_{2}$, $100 \mu \mathrm{M}$ 각각의 dATP, dCTP, dGTP, dTTP, $0.2 \mathrm{mM}$ primer, 2.1 units Taq DNA polymerase, $25 \mathrm{ng}$ 주형 DNA이다. PCR 반응을 위하여 추출한 각 분류군의 게놈 $\mathrm{DNA} 50 \mathrm{ng}$, 각 $\mathrm{dNTP}$
$100 \mathrm{uM}$, 시발체 각 $0.2 \mathrm{uM}, 1 \mathrm{x}$ enzyme buffer, Taq polymerase 2 units를 넣고 증류수로 전체 $50 \mu \mathrm{l}$ 이 되도록 추가하였다. 증폭반응은 초기 $94^{\circ} \mathrm{C} 90$ 초 변성한 후, 28 사이클로 $94^{\circ} \mathrm{C} 30$ 초, $42^{\circ} \mathrm{C} 60$ 초, $72^{\circ} \mathrm{C} 60$ 초간 실시하였고 추가로 $72^{\circ} \mathrm{C} 5$ 분간 연장하 였다.

증폭된 반응물질들은 $1.5 \%$ agarose gel에서 분리하였으며 ethidium bromide로 염색하여 밴드를 현상하였다. 이때 절편 들의 상대적 크기를 비교하기 위해 $100 \mathrm{bp}$ ladder DNA marker를 같이 loading시켰다. 이 젤을 ethidium bromide로 30 분 간 염색하여 밴드를 현상하였다. Alpha Image TM (Alpha Innotech Co, USA)을 사용하여 밴드 양상을 조사하였다. $\mathrm{RAPD}$ 는 재현성이 문제가 될 수 있으므로 모든 실험을 2회

Table 2. List of decamer oligonucleotide utilized as primers, their sequences, and associated fragments

\begin{tabular}{ccc}
\hline No. of primer & Sequence $\left(5^{\prime}-3^{\prime}\right)$ & No. of fragments \\
\hline OPC-01 & TTCGAGCCAG & 4 \\
OPC-02 & GTGAGGCGTC & 5 \\
OPC-03 & GGGGGTCTTT & 7 \\
OPC-04 & CCGCATCTAC & 4 \\
OPC-05 & GATGACCGCC & 9 \\
OPC-06 & GAACGGACTC & 5 \\
OPC-07 & GTCCCGACGA & 4 \\
OPC-08 & TGGACCGGTG & 5 \\
OPC-09 & CTCACCGTCC & 9 \\
OPC-10 & TGTCTGGGTG & 6 \\
OPC-11 & AAAGCTGCGG & 3 \\
OPC-13 & AAGCCTCGTC & 4 \\
OPC-19 & GTTGCCAGCC & 5 \\
OPC-20 & ACTTCGCCAC & 8 \\
Total & - & 78 \\
\hline
\end{tabular}

Table 1. The collected sites and codes of $B$. juncea

\begin{tabular}{cl}
\hline Code & \multicolumn{1}{c}{ Collection sites } \\
\hline 1 & Dongwol-ri, Gunnam-myeon, Yeonggwang-gun, Jeollanam-do \\
2 & Giryong-ri, Jangan-eup, Gijang-gun, Busan-si \\
3 & Yangsan-ri, Gyehwa-myeon, Buan-gun, Jeollabuk-do \\
4 & Dalsan-ri, Nampo-myeon, Boryeong-si, Chungcheongnam-do \\
5 & Goam-ri, Buk-myeon, Changwon-si, Gyeongsangnam-do \\
6 & Yongho-dong, Nam-gu, Busan-si \\
7 & Ganggu-ri, Ganggu-myeon, Yeongdeok-gun, Gyeongsangbuk-do \\
8 & Seomun-ri, Goheung-eup, Goheung-gun, Jeollanam-do \\
9 & Ucheon-ri, Sanam-myeon, Saceon-si, Gyeongsangnam-do \\
10 & Gupyeong-ri, Guryongpo-eup, Nam-gu, Pohang-si, Gyeongsangbuk-do \\
11 & Yeosu-si, Jeollanam-do (cultivated) \\
12 & Yeosu-si, Jeollanam-do (wild) \\
13 & Yeosu-si, Jeollanam-do (cultivated, Dolsan) \\
14 & Namdong-ri, Jindo-eup, Jindo-gun, Jeollanam-do \\
15 & Gonam-ri, Gonam-myeon, Taean-gun, Chungcheongnam-do \\
16 & Seongnae-ri, Haenam-gun, Jeollanam-do \\
17 & Sinsong-ri, Gobuk-myeon, Seosan-si, Chungcheongnam-do \\
\hline
\end{tabular}


실시하여 명확하게 일치하는 경우에만 분석에 사용하였다.

\section{데이터 분석}

각 다형성 RAPD 밴드는 유무에 따라 존재 시 1 , 부재 시 0 으로 이진법 처리하였다[6]. 여러 유전학적 표준 척도는 컴퓨 터 프로그램 POPGENE ver. 1.31 [22]를 사용하여 측정하였다. 다형현상을 나타내는 유전자좌위(polymorphic loci)의 퍼센트 $(P \mathrm{p})$, 유전자좌위당 대립유전자의 수 $(A)$, 유전자좌위당 유효 한 대립유전자의 수 $\left(A_{\mathrm{E}}\right), \mathrm{Nei}[18]$ 의 유전자 다양성 $(H)$, 샤논의 정보지수(Shannon's $I)$ 등으로 분석하였다[14].

분류군 간 유전적 거리(I)와 유전적 동질성 $(D)$ 은 분류군간 염기쌍의 비교로 산출하였다[20].

집단들 내 그리고 집단들 사이 유전적 다양성의 분포의 값 을 계산하기 위해 유전자 다양성 공식 $\left(H_{\mathrm{I}}, H \mathrm{~S}, \mathrm{G}_{\mathrm{T}}\right)$ 을 사용하 였다. 집단들 사이에 세대당 이주하는 유전자 이동 $\left(N_{\mathrm{m}}\right)$ 은 $N_{\mathrm{m}}=0.5\left(1 / G_{\mathrm{T}}-1\right)$ 로 계산하였다.

\section{군집 분석}

계통분석의 분지는 PHYLIP 버전 3.57[7]의 NEIGHBOR 프 로그램을 사용하였는데 이는 유전적 거리에 기초를 둔 neighbor-joining (NJ) 방법에 의해 구성하였다[20].

\section{결 과}

전체 14 개 시발체로 증폭한 결과 $\mathrm{OPC} 01$ primer, $\mathrm{OPC} 02$ primer, $\mathrm{OPC} 04$ primer, $\mathrm{OPC10}$ primer에서 잘 증폭이 일어난 반면, OPC12 primer, OPC14 primer, OPC15 primer, OPC16 primer, $\mathrm{OPC} 17$ primer, $\mathrm{OPC} 18$ primer, $\mathrm{OPC} 18$ primer는 증폭
이 일어나지 않았다(Table 2). 즉 겨자는 이들 시발체의 대응 서열이 없거나 반복된 이들 서열이 근연하게 배열되지 않음을 시사한다.

전체 14 개 시발체로 17 집단을 통합하여 분석 결과 78 loci가 나타났는데 그 중 60 의 loci는 다형성을 나타내었다 $(76.9 \%)$. 17집단 중 전남 진도 집단에서 $29.5 \%$ 로 가장 높은 반면, 전남 여수 재배종이 $12.8 \%$ 로 가장 낮았다(Table 3).

유전자좌위당 대립유전자 수 $(A)$ 는 1.128(전남 여수 재배종) 에서 1.295 (전남 진도 집단)까지 나타났으며 평균은 1.221 이였 다. 유전자좌위당 유효한 유전자 수( $A_{\mathrm{E})}$ 는 1.102(여수 재배종) 에서 1.234 (진도 집단)까지 나타났으며 평균은 1.167 이였다. 각 밴드의 다양성 빈도에 의한 유전적 다양성 $(H)$ 은 진도 집단이 0.127 로 가장 높았으며 여수 돌산갓이 0.069 로 가장 낮았다. 평균은 0.093 이였다. 표현형 다양도의 샤논 정보지수( $)$ 는 진 도 집단이 0.183 으로 가장 높았으며 여수 돌산갓이 0.080 로 가장 낮았다. 평균은 0.134 였다. 전반적으로 볼 때 겨자의 지역 간 다양도 차이는 중부지방보다는 남부지역이 높았으며 유의 성을 나타낸 반면, 전남 지역이 경상도 지역보다 높지만 유의 성은 없었다. 충남 보령 집단은 중부지방임에도 불구하고 다 양도가 크게 낮지 않았다. 한편 여수 돌산갓은 재배종으로 야 생종 겨자에 비해 다양도가 낮았다.

유전자좌위수준에서 전체 유전적 다양도 $\left(H_{\mathrm{I}}\right)$ 는 0.347 이였 으며 시발체 간 유의한 차이는 없었다(Table 4). 분집단의 유전 적 다양도 $\left(H H_{6}\right)$ 는 0.141 이였으며 시발체 간 유의한 차이를 나타 내었다. OPC-08은 분집단의 다양도는 나타내지 않았다. 집단 의 분화정도를 나타내는 $G_{5 T}$ 값은 0.587 이였으며 세대를 걸쳐 이주하는 개체수 $\left(N_{\mathrm{m}}\right)$ 는 0.617 이었다.

전체 유전자좌위는 78 개로 이들에 의한 유전적 동질성 지수

Table 3. Measurements of genetic variation for 17 populations of $B$. juncea in Korea

\begin{tabular}{ccccccc}
\hline Populations & $N \mathrm{p}$ & $P \mathrm{p}$ & $A$ & $A_{\mathrm{E}}$ & $H$ & $I$ \\
\hline 1 & 17 & 21.8 & 1.218 & 1.193 & 0.102 & 0.143 \\
2 & 19 & 24.4 & 1.244 & 1.192 & 0.104 & 0.150 \\
3 & 18 & 23.1 & 1.231 & 1.186 & 0.101 & 0.144 \\
4 & 20 & 25.6 & 1.256 & 1.184 & 0.103 & 0.151 \\
5 & 18 & 23.1 & 1.231 & 1.186 & 0.101 & 0.144 \\
6 & 17 & 21.8 & 1.218 & 1.167 & 0.092 & 0.133 \\
7 & 14 & 18.0 & 1.180 & 1.124 & 0.071 & 0.104 \\
8 & 20 & 25.6 & 1.256 & 1.164 & 0.096 & 0.143 \\
9 & 19 & 24.4 & 1.244 & 1.165 & 0.095 & 0.140 \\
10 & 15 & 19.2 & 1.192 & 1.129 & 0.075 & 0.110 \\
11 & 10 & 12.8 & 1.128 & 1.102 & 0.055 & 0.080 \\
12 & 19 & 24.4 & 1.244 & 1.205 & 0.109 & 0.155 \\
13 & 13 & 16.7 & 1.167 & 1.118 & 0.069 & 0.101 \\
14 & 23 & 29.5 & 1.295 & 1.234 & 0.127 & 0.183 \\
15 & 16 & 20.5 & 1.205 & 1.135 & 0.078 & 0.116 \\
17 & 18 & 23.1 & 1.231 & 1.193 & 0.103 & 0.147 \\
\hline Mean & 17 & 21.8 & 1.218 & 1.167 & 0.092 & 0.133 \\
\hline
\end{tabular}


Table 4. Estimates of genetic diversity of $B$. juncea. Total genetic diversity $\left(H_{1}\right)$, genetic diversity within populations $\left(H_{\xi}\right)$ proportion of total genetic diversity partitioned among populations $\left(G_{\mathrm{ST}}\right)$, and gene flow $\left(N_{\mathrm{m}}\right)$

\begin{tabular}{ccccc}
\hline Primer & $H_{\mathrm{T}}$ & $H_{5}$ & $G_{\text {ST }}$ & $N_{\mathrm{m}}$ \\
\hline OPC-01 & 0.431 & 0.206 & 0.508 & 0.093 \\
OPC-02 & 0.337 & 0.142 & 0.517 & 0.633 \\
OPC-03 & 0.246 & 0.067 & 0.644 & 0.401 \\
OPC-04 & 0.303 & 0.080 & 0.652 & 0.202 \\
OPC-05 & 0.286 & 0.095 & 0.711 & 0.276 \\
OPC-06 & 0.269 & 0.088 & 0.219 & 0.237 \\
OPC-07 & 0.496 & 0.388 & 0.500 & 1.815 \\
OPC-08 & 0.429 & 0.000 & 0.727 & 0.000 \\
OPC-09 & 0.255 & 0.057 & 0.865 & 0.219 \\
OPC-10 & 0.383 & 0.048 & 0.976 & 0.084 \\
OPC-11 & 0.289 & 0.009 & 0.100 & 0.012 \\
OPC-13 & 0.483 & 0.483 & 0.424 & 0.8007 \\
OPC-19 & 0.332 & 0.206 & 0.647 & 2.576 \\
OPC-20 & 0.316 & 0.111 & 0.584 & 0.291 \\
\hline Total & 0.349 & 0.144 & & 0.617 \\
\hline
\end{tabular}

와 유전적 거리를 산출하였다(Table 5). 유전적 동질성은 경상 북도 영덕 집단과 경상북도 포항 집단이 가장 높은 유전적 동질성을 나타내었다(0.986). 충청남도 태안 집단과 충청남도 서산 집단이 0.968 로 높았다. 부산시 용호동 집단과 경상남도 창원 집단, 경상남도 사천 집단이 0.934 0.939로 다른 집단과 비교할 때 역시 높았다. 이는 지리적으로 근연한 집단 간 유전 적 동질성이 높게 나타남을 시사하였다.

유전적 분화는 부산시 장안과 전라남도 해남의 땅끝 마을 집단, 충청남도 서산 집단을 제외하고 잘 분리되었다. 전라남 도 부안 집단과 영광 집단이 다른 집단과 분리된 양상을 나타 내었다(Fig. 1). 이들 집단에 대해 더 많은 시발체로 분석하면
보다 명확한 결과를 얻을 수 있을 것으로 판단된다.

\section{고 찰}

겨자는 일반적인 식물 종에 비해 낮은 유전적 다양도를 유 지하고 있었다. 예를 들면, 겨자의 유전적 다양도는 0.093 으로 유성생식과 무성생식을 가진 종(0.138), 온대지방의 식물 평균 (0.146), 초본 다년생 종(0.116)에 비해 낮은 값이다[9]. 다형성 을 나타내는 퍼센트 역시 낮았다. 겨자는 22.1\%였지만 유·무성 생식을 가진 종 $(43.8 \%)$, 초본 다년생 $(41.3 \%)$, 온대 지역 종 $(48.5 \%)$ 에 비해 낮았다[9]. 낮은 유전적 다양도를 나타내는 것

Table 5. Genetic identity (above diagonal) and genetic distances (below diagonal) at 17 populations of $B$. juncea based on RAPD

\begin{tabular}{|c|c|c|c|c|c|c|c|c|c|c|c|c|c|c|c|c|c|}
\hline Pop. & 1 & 2 & 3 & 4 & 5 & 6 & 7 & 8 & 9 & 10 & 11 & 12 & 13 & 14 & 15 & 6 & 17 \\
\hline 1 & 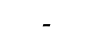 & 0.8209 & 986 & 0 & 0.7998 & & & & 0 & 4 & 55 & & 11 & 15 & .7896 & $t$ & 196 \\
\hline 2 & 1973 & - & 758 & 144 & 740 & & & 5 & 921 & 405 & 814 & & 13 & 32 & 7576 & 51 & .7740 \\
\hline 3 & 0.2249 & 0.2759 & - & 7 & 0.7257 & & 53 & & 119 & 192 & 919 & 36 & 91 & 491 & 919 & 69 & 123 \\
\hline 4 & 901 & 1692 & 2360 & - & 0.7922 & 0.8361 & & 98 & 0.8081 & 0.8274 & 0.7737 & & .7582 & 3698 & 8967 & 004 & 8896 \\
\hline 5 & 0.2234 & 1347 & 0.3207 & 0.2329 & - & 0.9417 & 0.8679 & 0.8325 & 0.9339 & 0.8688 & 0.7956 & 0.7665 & 0.7287 & 0.7811 & 0.6935 & 8187 & .7079 \\
\hline 6 & & & 702 & 790 & & - & 0.8911 & & 392 & 0.8854 & 0.8345 & & 372 & & 7287 & 624 & 7528 \\
\hline 7 & 22 & 680 & 211 & 0.1755 & 0.1417 & 0.11 & 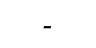 & 0. & 0.8582 & 0.9860 & 0.7751 & 0.7997 & 0.7495 & 7945 & 0.7385 & .8694 & 0.7722 \\
\hline 8 & & & & & & & & & & & & & 34 & & 25 & & \\
\hline 9 & 37 & 1142 & 398 & 0.2131 & 0.0684 & 0.0628 & 29 & 0.1762 & 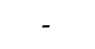 & 0.8836 & 0.8003 & 0.7754 & 0.7334 & 46 & 0.7079 & 0.8089 & 0.7284 \\
\hline 10 & & & & & & & & & & . & 0.7786 & & .7417 & & 06 & & \\
\hline 11 & & 2466 & 33 & 0.2566 & 0.2287 & 0.1810 & & 02 & 0.2228 & 0.2503 & 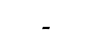 & 0.7589 & 0.8890 & & 0.7838 & 8184 & 0.8079 \\
\hline 12 & 848 & 2170 & 2698 & 0.1764 & 0.2660 & 0.2571 & 0.2236 & 0.1662 & 0.2544 & 0.2193 & 0.2759 & . & 0.7922 & 0.8653 & 0.8164 & .8697 & 0.8314 \\
\hline 13 & 0.2094 & 3129 & 756 & 0.2768 & 0.3165 & 0.2393 & 0.2884 & 0.2570 & 0.3101 & 0.2989 & 0.1176 & 0.2329 & . & .8593 & 0.7703 & .8420 & 0.8076 \\
\hline 14 & & & & 0.1395 & & & & & 0.2300 & 0.2406 & 0.1318 & & & & 0.8263 & 8566 & 0.8317 \\
\hline 15 & 0.2362 & 2776 & 2333 & 0.1091 & 0.3661 & 0.3165 & 0.3031 & 0.2200 & 0.3454 & 0.3003 & 0.2435 & 0.2029 & 0.2609 & 1907 & . & .8561 & 0.9684 \\
\hline 16 & 0.1538 & 1802 & 0.2396 & 0.1049 & 0.2000 & 0.1480 & 0.1399 & 0.0967 & 0.2121 & 0.1609 & 0.2004 & 0.1396 & 0.1719 & 0.1548 & 0.1553 & 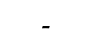 & 0.8731 \\
\hline 17 & 0.1989 & 2562 & 0.2079 & 0.1170 & 0.3454 & 0.2840 & 0.2586 & 0.2048 & 0.3169 & 0.2629 & 0.2133 & 0.1847 & 0.2137 & 0.1843 & 0.0321 & .1357 & - \\
\hline
\end{tabular}




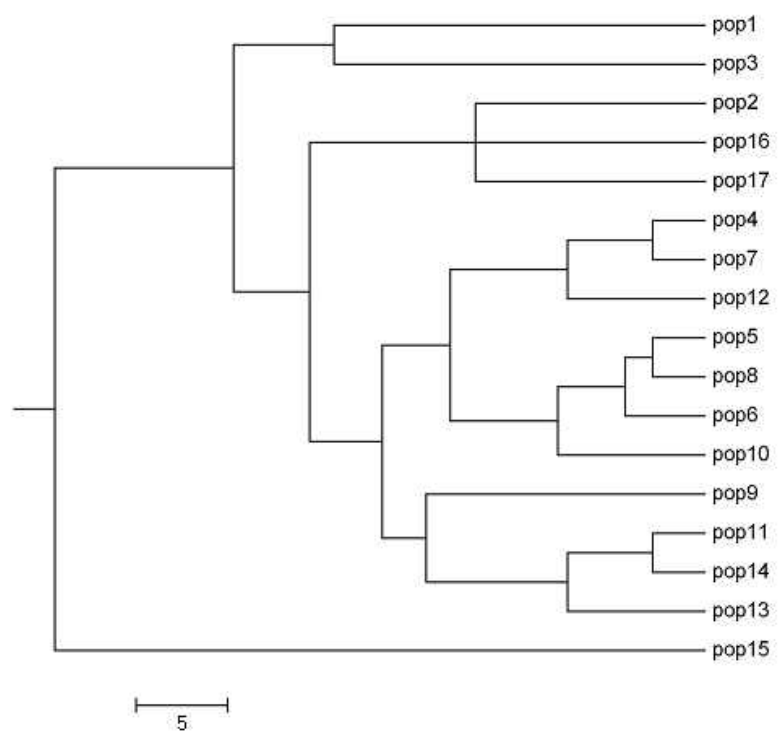

Fig. 1. A phenogram showing the relationships among 17 populations of $B$. juncea, based on data obtained by RAPD.

은 여러 생물학적 요인으로 설명된다. 첫째, 교배계에 따르면 타가수분이 우세한 종이 자가수분이나 영양번식이 우세한 종 에 비해 유전적 다양도가 높다[3,8]. 겨자는 타가수분보다 자가 수분이나 영양번식이 우세한 종이다. 둘째, 다년생 종은 보통 종은 돌연변이 축적 등의 원인으로 다양성이 높지만, 일년생 이나 이년생은 축적의 기회가 적다[15]. 겨자는 월동을 하지만 일년생 초본이다.

유전적 다양도와 집단 간 위도, 경도, 지리적 거리, 온도, 강수량 등과 상관관계를 조사하였다. 유전적 다양도와 집단 간 지리적 거리가 가장 높은 유의한 상관관계가 있었으며 유 전적 다양도와 위도가 유의한 상관관계가 있었다. 남쪽으로부 터 북으로 갈수록 다양도가 낮아졌다.

야생종에서 재배화를 통한 재배종 육성은 대부분의 경우 유전적 다양성이 저하되는 것으로 나타났다[1,5]. 물론 일부 종에서는 재배화가 여러 종의 교잡으로 유전적 다양도가 높아 지는 경우도 발견되었다. 예를 들면 보리, 메밀, 콩은 재배화가 일어나도 유전적 다양성이 전혀 부식되지 않았다[3,10,19].

집단 간 분화는 자연도태, 유전적 부동, 유전자 흐름 등으로 설명할 수 있다[15]. 겨자에서 전체 변이의 $58.9 \%$ 는 집단 간 차이로 설명된다 $\left(G_{\mathrm{st}}=0.589\right)$. 반면에 집단 간 유전적 흐름은 낮 았다 $\left(N_{\mathrm{m}}=0.617\right) . N_{\mathrm{m}}$ 이 1 이하이므로 유전적 부동이 상쇄되지 않아 유전적 부동이 집단 구조의 중요한 요인으로 작용함을 알 수 있다. 따라서 중부지역에 위치한 집단은 유전적 부동에 의한 유전적 다양성의 감소가 발견된다. 또한 집단의 크기의 문제이다. 일반적으로 집단의 크기가 작으면 큰 집단에 비해 유전적 다양성이 낮다[4]. 남쪽 집단은 큰 집단이 많고 인근 지역에서 많은 개체의 유입이나 교류가 있지만 중부 지역은 해안 지역으로 집단 간 거리가 멀고 집단이 형성되어 있어도
크기가 크지 않았다. 따라서 집단 간 새로운 유전자의 유입이 나 교류가 적게 일어난다고 볼 수 있다.

한편 이 등[12]에 의한 RAPD에 의한 여수 돌산갓에 대한 유연관계 분석이 있었다. 이들은 여수 돌산 갓을 일본 고체 품종인 '만생평경대엽'과 '청경대엽고채'가 일본에서 해방 이 후 돌산읍 세구지 마을에 도입되어 재배된 것으로 이전에 중 국에서 도입된 것으로 추정되는 한국 내 자생하던 종과 다르 다. 이들은 재료의 학명을 Brassica juncea 이라고 표기했는데 이는 교잡에 의한 재배종 돌산갓의 학명이 아니다. 또한 유전 적 다양도를 산출하지 않았으며 단지 유연관계를 나타내는 dendrogram을 제시하였으나 같은 계통이 다른 분지군에 위 치하는 등 잘 분리되지 않았으며 계통 간의 정보가 제시되지 않아 본 연구와 비교할 수 없었다.

종 보전을 위해 유전적 측면과 생태적 측면이 고려된다[17]. 해안지역에 주로 분포하는 겨자 집단은 낚시나 해안 도로 건 설, 해안 지역에 여러 상업, 관광시설이 여가문화와 더불어 증가하여 서식지를 위협하고 있다. 따라서 전라남도 해안 지 역의 겨자 집단은 다양성이 높고, 다른 집단에서는 그들만이 가지는 집단 특이 밴드가 발견되지 않았기 때문에 다양도가 높은 여러 집단군을 선정하여 유전자원 확보를 위해 보전이 필요하다.

\section{감사의 말씀}

본 논문은 2007학년도 동의대학교 연구년 지원에 의하여 연구되었음.

\section{References}

1. Aldrich, P. R., J. Doebley, K. F. Schertz, and A. Stee. 1992. Patterns of allozyme variation in cultivated and wild Sorghum bicolor. Theor. Appl. Genet. 85, 451-460.

2. Beebe, S., P. W. Skroch, J. Tohme, M. C. Duque, F. Pedraza, and J. Nienhuis. 2000. Structure of genetic diversity among common bean landraces of Middle American origin based on correspondence analysis of RAPD. Crop Sci. 40, 264-273.

3. Brown, A. H. D. 1978. Isozymes, plant population genetic structure and genetic conservation. Theor. Appl. Genet. 52, 145-157.

4. Chan, K. F. and M. Sun. 1997. Genetic diversity and relationships detected by isozyme and RAPD analysis of crop and wild species of Amaranthus. Theor. Appl. Genet. 95, 965-873.

5. Doebley, J. 1989. Isozymic evidence and the evolution of crop plants, pp. 46-72, In Soltis, D. E. and P. S. Soltis (eds.), Isozymes in Plant Biology, Dioscorides Press, Portland, OR.

6. Excoffier, L., P. E. Smouse, and J. M. Quattro. 1992. Analysis of molecular variance inferred from metric distances among DNA haplotypes: applications to human mitochondrial DNA restriction data. Genetics 131, 479-491.

7. Felsenstein, J. 1993. PHYLIP (Phylogeny Inference Package) 
Version 3.5s. Distributed by the Author. Department of Genetics, Univ. of Washington, Seattle.

8. Gottlieb, L. D. 1981. Electrophoretic evidence and plant populations. Progr. Phytochem 7, 1-46.

9. Hamrick, J. L. and M. J. W. Godt. 1989. Allozyme diversity in plant species, pp. 304-319 In Brown, A. H. D., M. T. Clegg, A. L. Kahler, and B. S. Weir (eds.), Plant population genetics, breeding and genetic resources, Sinauer Associates, Sunderland, MA

10. Kiang, Y. T. and M. B. Gorman. 1983. Soybean. pp. 295-328. In Tankley, S. D. and T. J. Orton (eds.), Isozymes in Plant Genetics and Breeding, Part A. Elsevier, Amsterdam.

11. Kresovich, S., J. G. K. Williams, J. R. McFerson, E. J. Routman, and B. A. Schaal. 1992. Characterization of genetic identities and relationships of Brassica oleraceae L. via a random amplified polymorphic DNA assay. Theor. Appl. Genet. 85, 190-196.

12. Lee, I. H., J. I. Park, O. S. Jeong, H. J. Jung, G. H. Jung, and I. S. Nou. 2010. Genetic relationship based on RAPD analysis of Yeosu Dolsan leaf mustard (Brassica juncea). $J$. Life Sci. 20, 66-70.

13. Lee, Y. N. 2007. New Flora of Korea. Kyo-Hak Publishing Co., Seoul, Korea.

14. Lewontin, R. C. 1972. The apportionment of human diversity. Evol. Biol. 6, 381-398.

15. Loveless, M. D. and J. L. Hamrick. 1984. Ecological determinants of genetic structure in plant populations. Annu. Rev. Ecol. Syst. 15, 65-95.

16. Molnar, S. J., L. E. James, and K. J. Kasha. 2000. Inheritance and RAPD tagging of multiple genes for resistance to net blotch in barley. Genome 43, 224-231.

17. Neel, M. C. and N. C. Ellstrand. 2003. Conservation of genetic diversity in the endangered plant Eriogonum ovalifolium var. vineum (Polygonaceae). Conserv. Gen. 4, 337-352.

18. Nei, M. 1973. Analysis of gene diversity in subdivided populations. Proc. Natl. Acad Sci. USA. 70I, 3321-3323.

19. Ohnishi, O. and N. Asano. 1999. Genetic diversity of Fagopyrum homotropicum, a wild species related to common buckwheat. Genet. Resour. Crop Evol. 46, 389-398.

20. Saitou, N. and M. Nei. 1987. The neighbor-joining method: A new method for reconstructing phylogenetic trees. Mol. Biol. Evol. 4, 406-425.

21. Welsh, J. and M. McClelland. 1990. Fingerprinting genomes using PCR with arbitrary primers. Nucleic Acids Res. 18, 7213-7218

22. Yeh, F. C., R. C. Yang, and T. Boyle. 1999. POPGENE Version 1.31, Microsoft Windows-based Freeware for Population Genetic Analysis. University of Alberta, Alberta.

\section{초록 : RAPD를 이용한 겨자의 유전적 다양성과 집단구조}

$$
\begin{aligned}
& \text { 오영희 }^{1} \cdot \text { 문성기 }\left.\right|^{2} \cdot \text { 채양희 }^{2} \cdot \text { 홍화진 }^{2} \text { - 조철민 · 박소혜 · 허만규 } \\
& \text { (동의대학교 분자생물학과, }{ }^{1} \text { 동의대학교 화학과, }{ }^{2} \text { 경성대학교생물학과) }
\end{aligned}
$$

본 연구는 우리나라 겨자 17집단에 대한 유전적 다양도와 집단구조를 조사하였다. 60 개의 다형성 좌위와 18 개 단형성 좌위가 발견되었다. 다형성 밴드의 비율은 전남 진도 집단이 가장 높았으며 재배종이 가장 낮았다. 대립유 전자좌위의 수는 1.221 이였으며 유효한 대립유전자좌위의 수는 1.167 이였다. 이 종의 전형적인 집단은 작고 격리 되어 낮은 유전적 다양도를 가지고 있었다. 전체 다양도는 0.347 이였으며 집단 내 다양도는 0.141 이였다. 집단간 분화를 나타내는 척도는 0.589 였다. 아는 $58.9 \%$ 의 다양도가 집단간에 있음을 시사한다. 세대 간 이주하는 개체수 는 0.617 로 낮았다. RAPD는 겨자 집단을 구분하는데 유익하였다. 